\title{
EVALUATION OF ANTIBACTERIAL ACTIVITY OF INDONESIAN VARIETIES SWEET POTATO LEAVES EXTRACT FROM CILEMBU AGAINST SHIGELLA DYSENTERIAE ATCC 13313
}

\author{
SRI AGUNG FITRI KUSUMA*, ULFA TRI WAHYUNI, ADE ZUHROTUN \\ Department of Pharmaceutical Biology, Faculty of Pharmacy, Padjadjaran University, Sumedang, West Java, Indonesia. \\ Email: s.a.f.kusuma@unpad.ac.id
}

Received: 20 October 2016, Revised and Accepted: 28 October 2016

\section{ABSTRACT}

Objective: The aim of this study was to evaluate the in vitro antibacterial activity of sweet potato (Ipomoea batatas [L.] Lam) leaves ethanol extracts against Shigella dysenteriae ATCC 13313.

Methods: The study was performed by collecting and determining plant samples, extraction, moisture content assay, phytochemical screening, thin-layer chromatography, antibacterial activity using agar-diffusion method using perforator of $11 \mathrm{~mm}$ in diameter and minimum inhibitory concentration (MIC) test using macrodilution method against S. dysenteriae ATCC 13313.

Results: Phytochemical analysis of the sweet potato leaves extract revealed the presence of flavonoids, tannin, steroid, and polyphenolic compound. Sweet potato leaves ethanol extract showed a significant zone of inhibition in a dose-dependent manner against S. dysenteriae ATCC 13313 with the range of MIC was $10-20 \% \mathrm{w} / \mathrm{v}$.

Conclusion: It can be concluded that the sweet potato leaves ethanol extracts shows promise as an antibacterial agent for inhibiting bacillary dysentery due to the presence of biologically active ingredients with antimicrobial activity in the extract.

Keywords: Sweet potato, Cilembu, Indonesia, Antidysentery, Shigella dysenteriae ATCC 13313.

(C) 2017 The Authors. Published by Innovare Academic Sciences Pvt Ltd. This is an open access article under the CC BY license (http://creativecommons. org/licenses/by/4. 0/) DOI: http://dx.doi.org/10.22159/ajpcr.2017.v10i2.15773

\section{INTRODUCTION}

Bacillary dysentery is a digestive tract infection caused by Shigella dysenteriae. Initial signs and symptoms include abdominal pain, cramping, and fever followed by frequent watery stools [1]. In some developing countries, the disease is endemic and occurs every year 80 million cases with 700,000 fatalities. Most of the dysentery patients are children under 5 years old [2].

Treatment of bacillary dysentery can be done with antimicrobial agents such as ciprofloxacin, pivmecillinam, ceftriaxone and azithromycin [2]. However, it has been reported that ciprofloxacin, ceftriaxone, and azithromycin have been resistant to $S$. dysenteriae [3,4]. Therefore, alternative treatment against dysentery from herbal products is required. One of them is done by the sweet potato (Ipomoea batatas [L]. Lam) leaves.

Usually, the only part of sweet potato plants which commonly used is the tuber. However, the young leaves of sweet potato leaves are also widely consumed as a vegetable. In addition to good taste, sweet potato leaves (I. batatas L.) content of health-promoting phytochemicals. Sweet potato leaves have been investigated, are a good source of vitamins $\mathrm{A}, \mathrm{C}, \mathrm{B}_{2}$ (riboflavin) and $\mathrm{D}$, fat- and cholesterol-free, high in beta-carotene, and lutein. The mineral content of this leaf, such as iron, magnesium, and potassium, was high in leaves in comparison with other vegetables. Furthermore, total polyphenol and flavonoid content are comparatively high [5]. This data can be correlated with the research that shows the antimicrobial activity of sweet potato leaves against Staphylococcus aureus, Bacillus cereus, and Escherichia coli [6].

Scientific evidence on the antibacterial ability of sweet potato leaves against other bacteria because of its antibacterial secondary metabolite content, made sweet potato leaves can be utilized as natural and safe bacillary antidysentery. In addition, potassium and other mineral contents can be used as a mineral supply for preventing dehydration. By combining both mechanisms, hopefully can produce new antidysentery which can reduce the mortality rate due to excessive diarrhea and dehydration. Based on this background, we conducted the research on the antimicrobial activity of sweet potato leaves against $S$. dysenteriae ATCC 13313.

\section{MATERIALS AND METHODS}

\section{Materials}

The plant that was utilized in this study is Cilembu sweet potato leaves from Cilembu, Sumedang, West Java. The bacteria that were used is $S$. dysenteriae ATCC 13313. The culture media that were used are Mueller-Hinton agar (MHA), Mueller-Hinton Broth (MHB), and Shigella salmonella agar (SSA). The chemicals used are distilled water, water fuchsin, alcohol 70\%, alcohol 96\%, amyl alcohol, ammonia, disinfectant, dimethylsulfoxide, chloroform, acetic acid solution, physiological $\mathrm{NaCl}$ solution $0.9 \%$, barium chloride solution, sulfuric acid solution, Lugol's solution, n-butanol (Bratachem), ferric chloride reagent, Dragendorf reagents, Liebermann - Burchard reagent Mayer, carbon dye gentian violet, technical toluene, and vaseline.

\section{Samples preparation}

Leaves bulbs used were obtained from plants that were 2-3 months. It was obtained from the sweet potato farm in Cilembu village, Pamulihan sub-district, Sumedang Regency. Plant samples were identified in Plant Taxonomy Laboratory of Biology Major, Faculty of Mathematics and Natural Science Padjadjaran University. Sweet potato leaves were extracted by using a maceration method using ethanol $70 \%$ as the solvent. Extract then was evaporated using a rotary evaporator at 40$50^{\circ} \mathrm{C}$ and then continued using a water bath at $40-50^{\circ} \mathrm{C}$ until dried extract with a constant weight was obtained. 
Examination of extract quality

The examination of extract quality was done, including phytochemical screening and thin-layer chromatography (TLC) assay. Phytochemical screening was done by using Farnsworth method to determine the contain of alkaloids, flavonoids, tannins, quinones, phenolics, saponins, steroids, triterpenoids, monoterpenoids, and sesquiterpenoids in the ethanol extract of sweet potato leaves [7]. TLC assay was conducted using silica gel GF254 as the stationary phase and the upper layer of butanol, acetic acid, water (4:1:5) that had been saturated for $24 \mathrm{hrs}$ as the moving phase. The extract was spotted on silica gel then prepared in the solvent. The compound then was analyzed under ultraviolet light 254 and $366 \mathrm{NM}$

\section{Confirmation of testing bacteria}

Confirmation of the tested bacteria was done, including morphological observation of the colony morphology, cell shape, and biochemical assay. Observation of colony morphology was achieved by culturing the bacteria into SSA. Observation of cell shape was done with Gram staining method [8]. The biochemical assay was done, including motility, carbohydrate fermentation, Indole, hydrogen sulfate, urea hydrolysis, methyl red, Voges-Proskauer, and Simmon citrate [9]

\section{Antibacterial activity}

The antibacterial activity test was done with the agar diffusion method. The volume of $20 \mathrm{ml}$ MHA was poured into a sterilized petri dish, then $20 \mu \mathrm{l}$ bacterial suspensions with 0.5 McFarland in turbidity was added. The mixture of bacterial suspension and agar was homogenized until it became solid. By utilizing perforation method, we made four holes in the agar [10]. The extract was solved on dimethyl sulfoxide with the comparison $1 \mathrm{~g}$ of extract was solved in $1 \mathrm{ml}$ of dimethyl sulfoxide $(100 \% \mathrm{w} / \mathrm{v})$. Then, the extract solution was done with the variation of concentration $20,40,60$, and $80 \%$ using dimethyl sulfoxide. The volume of $50 \mu \mathrm{l}$ of every extract concentration was populated and poured into the hole. The media then was incubated for $20 \mathrm{hrs}$ at temperature $37^{\circ} \mathrm{C}$. After that, we observed the inhibitory zones around the holes.

\section{Statistical analysis}

The result of antibacterial activity of sweet potato leaves extracts against S. dysenteriae ATCC 13313 then was statistically analyzed using ANOVA method with the hypothesis below:

$\mathrm{H}_{0}=$ There is no effect on treatment,

$\mathrm{H}_{1}=$ At least there is one treatment that, affected the bacterial growth.

Minimum inhibitory concentration (MIC) and minimum bactericidal concentration determination

MIC test was done with macrodilution method. The volume of $1 \mathrm{ml}$ MHB was added to every sterilized tube. Then, $1 \mathrm{ml}$ extract with concentration $40 \% \mathrm{w} / \mathrm{v}$ was added into the first tube. Then, from the first tube, we took $1 \mathrm{ml}$ and added to the second tube and we did it until the concentration of every tube was $20 \% ; 10 \% ; 5 \% ; 2.5 \% ; 1.25 \%$; and $0.625 \% \mathrm{~b} / \mathrm{v}$. Then, $10 \mu \mathrm{l}$ of bacterial suspension $(0.5 \mathrm{McFarland}$ turbidity standards) was added to every tube. The liquid media then were incubated for $20 \mathrm{hrs}$ with temperature $37^{\circ} \mathrm{C}$. MIC was determined from the smallest concentration which did not show any turbidity. The bacterial growth detection test was done using the streak plate method. The loop was dipped into the MIC tube, then streaked it to the agar. After that, it was incubated for 20 hrs at temperature $37^{\circ} \mathrm{C}$. MIC was established from the smallest concentration that did not show any bacterial growth.

\section{RESULTS AND DISCUSSION}

The result of the plant determination showed that the plant that was used in this study is I. batatas L. The consequence of extraction is from the $342 \mathrm{~g}$ of leaves, $20 \mathrm{~g}$ of extracts was obtained. An ethanol extract of sweet potato has dark green color, bitter flavor, and odor.

The examination of extract quality was done by doing phytochemical screening and TLC assay. The result of phytochemical screening can be seen in Table 1.
Phytochemical screening was done to know the secondary metabolite compound of sweet potato leaves ethanol extracts. Based on the data in Table 1, the ethanol extract of sweet potato leaves contains flavonoids, tannins, polyphenolics, and steroid compound. The result of phytochemical screening above was same as the result that had been done by Mailawani [11]. Components of secondary metabolites in the extract can integrate with each other or work, respectively, to produce antibacterial activity against $S$. dysenteriae.

The purpose of TLC assay was to determine the profile of the active compound which is contained in the extract. The result of TLC assay can be seen in Table 2 .

Based on the result, there were two spots on a TLC plate. That means at least, there were two secondary metabolites that contained in the extract.

Confirmation test was done to assure the genus and species of bacteria that were used in this study. We did the observation of colony morphology, Gram-staining, and biochemical assay. Observation of colony morphology was done by culturing the bacteria on SSA medium. The color of the bacterial colony was straw-colored. This result was comparable as the literature that said the color of Shigella sp. bacterial colony was straw-colored. The result can be seen in Fig. 1.

Gram staining was done to determine the shape of the bacterial cell. We used carbon gentian violet as the primary stain and fuchsine as a counter stain. Based on the observation under the microscope has a magenta color has bacillus shape and does not have flagella. The result of Gram-staining can be viewed on Fig. 2.

The biochemical assay was done to see the characteristic of bacteria based on the biochemical reaction (whether it has degradation enzyme or not) using several reagents. The result of the biochemical assay can be seen in Table 3 .

The result in Table 3 showed that the bacteria can only ferment glucose and gave a positive result on methyl red assay. Based on the series of tests that we had done, we conclude that the bacteria that we were going to used was Shigella dysentery.

The antibacterial activity test was done using the agar diffusion method with perforation technique. The test was done with $80 \% ; 60 \% ; 40 \%$; and $20 \% \mathrm{w} / \mathrm{v}$ extract concentration in dimethyl sulfoxide solvent. The result of the antibacterial activity test can be seen in Table 4

Table 1: Phytochemical screening

\begin{tabular}{ll}
\hline Compounds & Results \\
\hline Alkaloids & - \\
Flavonoids & + \\
Tannins & + \\
Polyphenolics & + \\
Monoterpenoids and Sesquiterpenoids & - \\
Steroids & + \\
Triterpenoids & - \\
Quinones & - \\
Saponins & - \\
\hline
\end{tabular}

$(+)=$ Detected; $(-)=$ Not detected

Table 2: TLC assay results

\begin{tabular}{lllll}
\hline Spot number & Rf & Visible light & \multicolumn{2}{l}{ UV light (nm) } \\
\cline { 4 - 5 } & & & $\mathbf{2 5 4}$ & $\mathbf{3 6 6}$ \\
\hline 1 & 0.875 & Green & Green & Red \\
2 & 0.625 & Brown & Brown & Yellow \\
\hline
\end{tabular}

TLC: Thin-layer chromatography, UV: Ultraviolet 


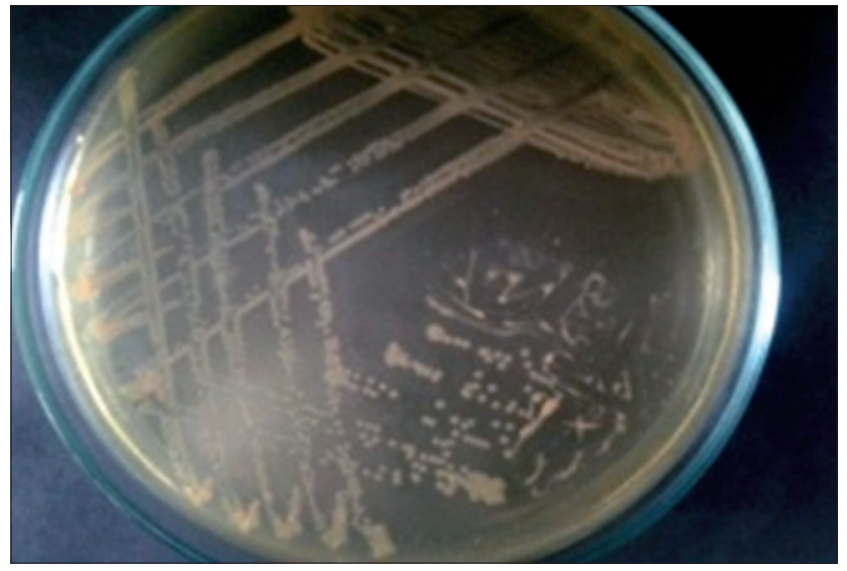

Fig. 1: Shigella dysenteriae colony in salmonella Shigella agar

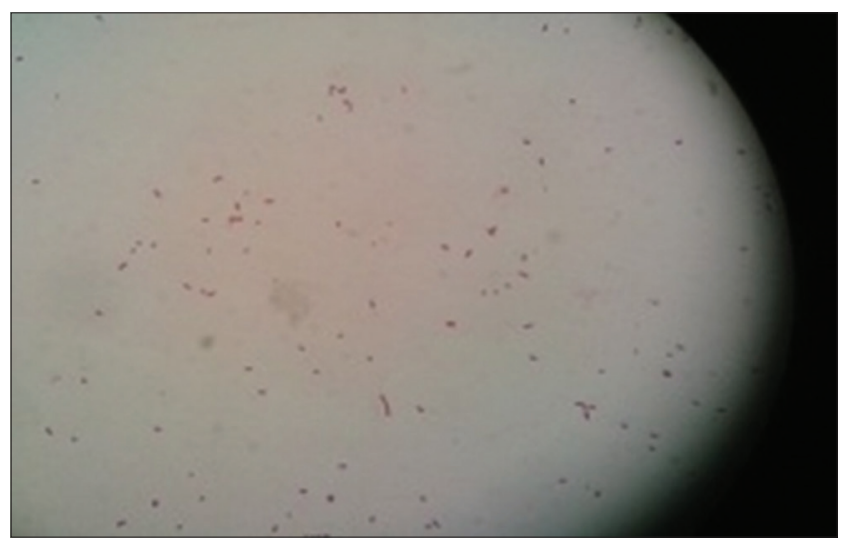

Fig. 2: Shigella dysenteriae cell

From the data that was shown in Table 4, we could see that sweet potato leaves ethanol extract has acted as an antibacterial agent against Shigella dysentery. The greater concentration that we used the bigger diameter of the inhibitory zone. The antibacterial activity test was a qualitative test. It determined whether the extract had antibacterial activity against $S$. dysenteriae. Based on the diameter of inhibition zones, all tested concentrations of the extract were categorized as a very active antibacterial (above $11 \mathrm{~mm}$ ) [12]. Antibacterial activity of testing extracts against $S$. dysenteriae because of the content of secondary metabolites in extracts that are an antibacterial agent. This is similar to ethanol extract of Pithecellobium dulce (Roxb.) Benth leaves which have antibacterial activity only to $S$. dysenteriae among 10 other tested bacteria because of the same content of secondary metabolites with sweet potato extracts also contained flavonoids [13]. The same result also reported on another study that the bark extract of Terminalia arjuna showed potential antimicrobial activities against all of the selected strains of microorganisms, and the greatest activity were observed against $S$. dysenteriae [14].

The result of the antibacterial activity of extract against $S$. dysenteriae was analyzed using one-way ANOVA method with $\alpha=0.05 \%$. The result of statistical analysis can be seen in Table 5 .

Based on the statistical analysis result, we rejected $\mathrm{H}_{0}$ and accepted $\mathrm{H}_{1}$ and we concluded that at least there is a treatment that affected the bacterial growth.

The determination of MIC was done by using macrodilution method. We did this step to ascertain the smallest concentration that still can inhibit the bacterial growth. Media, extract and bacterial control were required to compare the turbidity result. The colors of extract scattered the
Table 3: Biochemical assay result

\begin{tabular}{lll}
\hline Assay & Tested S. dysenteriae & Reference \\
\hline Motility & - & - \\
Glucose & + & + \\
Lactose & - & - \\
Manose & - & - \\
Maltose & - & - \\
Saccharose & - & - \\
Indole & - & - \\
$\mathrm{H}_{2} \mathrm{~S}$ & - & - \\
Urea & - & - \\
Methyl red & + & + \\
Voges Proskauer & - & - \\
Simmon citrate & - & - \\
\hline
\end{tabular}

$+=$ present, -=absent. S. dysenteriae: Shigella dysenteriae

Table 4: The result of antibacterial activity

\begin{tabular}{ll}
\hline Concentration (\%) & Diameter of inhibitory zone (mm) \\
\hline 80 & $19.60 \pm 0.10$ \\
60 & $17.00 \pm 0.40$ \\
40 & $16.45 \pm 0.15$ \\
20 & $14.05 \pm 0.15$ \\
\hline
\end{tabular}

Perforator diameter $=11 \mathrm{~mm}$

Table 5: Statistical analysis result

\begin{tabular}{llllll}
\hline Result & Su & df & Mean & F & Ft \\
\hline Treatment & 32.27 & 3 & 10.757 & 105.46 & 15.1 \\
Error & 0.41 & 4 & 0.1025 & & \\
Total & 32.68 & 7 & & & \\
\hline
\end{tabular}

Table 6: MIC values of testing bacteria

\begin{tabular}{ll}
\hline Concentration $(\%)$ & Colony growth \\
\hline Negative control & - \\
Extract control & - \\
20 & - \\
10 & + \\
5 & + \\
2.5 & + \\
1.25 & + \\
0.625 & + \\
Positive control & + \\
\hline
\end{tabular}

$(+)=$ There is colony growth; $(-)=$ There is no colony growth. MIC: Minimum inhibitory concentration

turbidity, so we needed to streak the broth on agar media to determine the MIC level. The variation concentration that we used were $20 \%$, $10 \%, 5 \%, 2.5 \%, 1.25 \%$, and $0.625 \%$. The result of MIC test can be seen in Table 6.

MIC was determined from the smallest concentration that shows the smallest bacterial growth and confirmed the result by determining the smallest concentration that did not show any bacterial growth. From the Table 4, it can be determined that the MIC range of sweet potato leaves ethanol extracts against $S$. dysenteriae was $10-20 \% \mathrm{w} / \mathrm{v}$. This MIC value indicating that the extracts are bacteriostatics at lower concentrations than $20 \% \mathrm{w} / \mathrm{v}$.

\section{CONCLUSION}

Based on the study that had been done, the ethanol extract of sweet potato leaves had antibacterial activity against $S$. dysenteriae. The range of MIC was between $10 \%$ and $20 \% \mathrm{w} / \mathrm{v}$. An ethanol extract of sweet potato leaves contain some antibacterial secondary metabolites such as flavonoids, phenolics, tannins, and steroid compound. 


\section{REFERENCES}

1. DiPiro JT, Talbert RL, Yee G, Matzke G, Wells BG, Posey LM. Pharmacotherapy: A Pathophysiologic Approach. $7^{\text {th }}$ ed. United States: McGraw-Hill; 2008

2. World Health Organization. Guidelines for the Control of Shigellosis, Including Epidemics due to Shigella dysenteriae 1. Switzerland: WHO Document Production Services; 2005.

3. Rahman M, Shoma S, Rashid H, El Arifeen S, Baqui AH, Siddique AK, et al. Increasing spectrum in antimicrobial resistance of Shigella isolates in Bangladesh: Resistance to azithromycin and ceftriaxone and decreased susceptibility to ciprofloxacin. J Health Popul Nutr 2007;25(2):158-67.

4. Bhattacharya D, Sugunan AP, Bhattacharjee H, Thamizhmani R, Sayi DS, Thanasekaran K, et al. Antimicrobial resistance in Shigellarapid increase \& widening of spectrum in Andaman Islands, India. Indian J Med Res 2012;135 Suppl 3:365-70.

5. Khachatryan A, Basonde RR, Labonte DR, Losso JN, Bansode RR, Labonte DR, et al. Identification of sweet potato leaves (Ipomoea batatas) as an excellent source of lutein. Session 88 of Nutraceutical and Functional Foods. Chicago, IL: McCormick Place; 2003.

6. Islam MS, Jalaluddin M. Antimicrobial activities of Ipomoea batatas leaves grown under different environmental conditions. Proceedings of the $49^{\text {th }}$ Annual Rural Life Conference. USA: University of Arkansas; 2005. p. 23.

7. Fansworth NR. Biology and phytochemical screening of plants. J Pharm Sci 1966;55 Suppl 3:263-4.
8. Public Health England. UK Standards for Microbiology Investigations: Gram Procedures. Available from: https:/www.gov.uk/government/ uploads/system/uploads/attachment_data/file/344141/TP_39i1.2.pdf. [Last accessed on 2014 Dec 30].

9. Holt JG, Krieg NR, Sneathm PH, Staley JT, Williams ST. Bergey's Manual of Determinative Bacteriology. $9^{\text {th }}$ ed. Baltimore: Williams and Williams Publishers; 1994.

10. Mailawaini LH. Testing leaf extract sweet potato (Ipomoea batatas (L). Poir) and herb gotu kola (Centella asiatica (L). Urb.) About the amount of platelets, erythrocytes, and hematocrit levels in rats Wistar strain. Jatinangor. Faculty of Pharmacy UNPAD; 2012.

11. Oxoid. Salmonella Shigella Agar, 2011. Available from: http://www.oxoid.com/UK/blue/prod_detail/prod_detail. asp? $\mathrm{pr}=\mathrm{CM} 0099 \&$ org $=128 \& \mathrm{c}=\mathrm{UK} \&$ lang $=\mathrm{EN} /$. $\quad$ Last accessed on 2014 Dec 29].

12. Nurliana, Sudarwanto M, Sudirman LI, Sanjaya AW. The Prospect of Acehnese Traditional Foods as a Healthy Food: The Initial Detection of Antimicrobial Activity of Plieku Oil and Plieku Crude Extracts. Dissertation, Veterinary Science Study Program. Bogor Agricultural Institute, 2009

13. Mohammed HU, Sujit B, Mohammed AM, Amdadul H, Jamilur RB. Phytochemical screening and analgesic, anti-bacterial and cytotoxic activity evaluation of ethanol extract of Pithcellobium dulce (Roxb.) Benth leaf. Asian J Pharm Clin Res 2015;8(2):454-7.

14. Alam MM, Azim U, Akhlaqur R, Tahrim H, Sahrov R, Abdullah A, et al. In vitro antimicrobial and cytotoxicity screening of Terminalia arjuna ethanol extract. Int J Biosci 2011;1 Suppl 2:31-8. 